\title{
Home Garden With Eco-Healing Functions Benefiting Mental Health and Biodiversity During and After the COVID-19 Pandemic: A Scoping Review
}

OPEN ACCESS

Edited by:

Wulf Rössler,

Charité - Universitätsmedizin

Berlin, Germany

Reviewed by:

Ye Liu,

Sun Yat-sen University, China

Zheng Feei Ma,

Universiti Sains Malaysia Health

Campus, Malaysia

*Correspondence:

Yixin Zhang

yixin.zhang2019@suda.edu.cn

Specialty section:

This article was submitted to

Public Mental Health

a section of the journal

Frontiers in Public Health

Received: 26 July 2021

Accepted: 11 October 2021

Published: 11 November 2021

Citation:

Zhang XD, Zhang YX and Zhai

(2021) Home Garden With

Eco-Healing Functions Benefiting

Mental Health and Biodiversity During and After the COVID-19 Pandemic: A

Scoping Review.

Front. Public Health 9:740187. doi: 10.3389/fpubh.2021.740187

\begin{abstract}
Xindi Zhang ${ }^{1}$, Yixin Zhang ${ }^{1,2 *}$ and Jun Zhai ${ }^{1}$
${ }^{1}$ Department of Landscape Architecture, Soochow University, Suzhou, China, ${ }^{2}$ Collaborative Innovation Center of Architecture and Urban Environment of Soochow University-Suzhou Yuanke; China-Portugal Belt and Road Cooperation Laboratory of Cultural Heritage Conservation Science, Research Center of Landscape Protection and Ecological Restoration, Soochow University, Suzhou, China
\end{abstract}

The COVID-19 pandemic has led to tremendous impacts on human lives and society, which are not only because of negative effects on people's mental health due to isolation policies and physical distance for mitigating the spread of SARS-CoV-2, but also because the incident post-acute sequelae of the coronavirus will cause mental disorders. A green environment is a health resource, which cannot only benefit human physical and mental health, but also increases biodiversity, contributes to flood mitigation, and cools urban areas. A home garden, as a kind of small green space, can provide ecosystem services with eco-healing functions in reducing mental stress during the isolation period of the COVID-19 pandemic through the garden itself and physical activities in it. Such an eco-healing approach within a mini-therapeutic landscape can also benefit biodiversity by enhancing plant diversity in residence and increasing biodiversity at a large scale. In this article, we propose a conceptual framework describing a home garden as "ecological medicine" with healing functions to improve mental health, as well as indirectly enhancing urban biodiversity. A home garden, as a mini-type of green landscape with biodiversity content, allows people to get close with nature so that it can promote comfortable and natural feelings during the pandemic. Furthermore, such an eco-healing home garden approach benefiting urban biodiversity can meet the challenges in maintaining environmental and mental health in post COVID-19 pandemic recovery, as well as preparing unknown next-surge risks with potential isolation regulations.

Keywords: green environments, biodiversity, ecosystem services, nature-based-solution, plants and animals

\section{INTRODUCTION}

The 2019 coronavirus disease (COVID-19) pandemic sweeping the world has had a profound impact on all aspects of human society. It was calculated that the global cumulative number of people suffering from COVID-19 was over 157 million, and the death rate had reached 3.29 million in May 2021 (1). Throughout the COVID-19 pandemic, countries have enforced stay-at-home advisories or shelter-in-place and border control policies to control the spread of the coronavirus SARS-CoV-2. And now, as the pandemic is almost under control, policies have changed, stating 
that residents or visitors entering from abroad should be tested for COVID-19 and quarantined for more than 14 days immediately.

The policies during the pandemic reduced the likelihood of people getting along with others $(2,3)$, and the loneliness of isolation accompanied by the fear of the COVID-19 pandemic, the stress of economic downturn, and the increasing amount of unemployment also affected people's mental health (4-9). It indicated that the proportion of the population suffering from depression during the COVID-19 pandemic in the U.S. was three times higher than before $(4,10)$. And data collected from the Household Pulse Survey showed that more than 35\% of adults in the U.S. experienced anxiety or depressive disorder during February to March 2021, while the data collected from January to June 2019 were $8.2 \%$ for anxiety disorder, $6.6 \%$ for depressive disorder, and $11.0 \%$ for anxiety or depressive disorder. A highdimensional approach also identified that incident post-acute sequelae of the COVID-19 included neurocognitive disorders and mental disorders (11). In the long run, mental health risks associated with the COVID-19 pandemic can be more harmful than the virus itself $(12,13)$. Thus, it is necessary to find a green and sustainable solution to meet the challenges.

For mental disorders, the traditional treatment is psychiatric medication (14-16). However, the use of medications can have unwarranted side effects. In addition, traditional psychiatric treatment may be associated with stigmatizing attitudes in general, while complementary or alternative therapies are widely accepted (17), such as plant and horticultural therapy.

Plant-based or gardening-based horticultural therapy can lead to a reduction in the prevalence of distress such as depression, stress, and anxiety, and they can improve mental health $(18,19)$. The rehabilitative effects of horticultural therapy are based on the theories of green spaces' healing functions to benefit people not only physically but also psychologically (20-24). These healing functions depend on the health of the human environment, the functions of the ecosystem $(25,26)$, and biodiversity (27). The promoting effects are positively correlated with the increase of greenness and proximity to green space (28). And the main benefit is that more physical exercise in green space can have effects on reducing greenhouse gas emissions and enhancing more appreciation of natural environment and biodiversity (29). The established aspects of green space with biodiversity can make significant contributions to physical and mental health $(25,27)$.

Based on the theories of psychological treatment and horticultural therapy, the concept of "ecological medicine," which is one type of nature-based solution, has emerged for improving mental health through natural space. "Ecological medicine" mainly refers to a home garden and home gardening in this article because the isolation policies reduced the opportunities of access to public green space during the COVID-19 pandemic, and a home garden can provide mental health services in limited areas. Especially, "ecological medicine" has not only therapeutic effects, but also ecological and sustainable effects, such as lowering the temperature, improving air quality, and increasing urban biodiversity. The objectives of this article dealing with the home garden are: (a) reviewing and examining how a home garden, a kind of green space, can contribute to mental health during the
COVID-19 pandemic and in the future, and (b) exploring the positive effects of home gardening, a kind of physical activity, on mental health during the isolation period.

\section{CONCEPTUAL MODEL}

For achieving mental health and benefiting biodiversity through green space, a conceptual model of green space (home garden) for biodiversity and mental health under the COVID-19 pandemic is proposed (Figure 1). The logical framework of green space (home garden) to improve mental health is linked to its ecohealing effects as "ecological medicine" in reducing mental problems and stress which are caused by being unable to visit green spaces and parks.

\section{METHODS}

\section{Strategy for Selection of Articles}

In order to carry out the scoping review, electronic journal databases (Web of Science, Science Direct, Google Scholar, Johns Hopkins University and Medicine, WHO, and other databases) were used to collect literature and other information. Firstly, over 200 articles in the last 20 years were selected by searching topic words including human health (set 1: "the COVID-19," "psychological health," "mental health," or "morbidity"), green space (set 2: "green space," "home garden," "balcony garden," or "biodiversity"), and activities (set 3: "home gardening"). At the same time, psychological health or mental health was combined with some keywords like COVID-19, green space, home garden, balcony garden, and home gardening. For a thorough understanding, references in relevant articles were also reviewed. Secondly, to be included in the article, literature had to meet the following criteria through a review of the abstract, introduction, and methods: (a) first-hand research articles were preferred, (b) findings were directly applicable to the mental health promotion of home garden or home gardening, and (c) articles had high impact. Based on these, over 100 articles from 68 scientific journals in health, medicine, ecology, landscape, environmental sciences, and other relevant areas were finally selected. Lastly, we divided the collected articles into two categories: (a) the positive influence of a home garden on mental health, and (b) the promotion of home gardening on mental health (Table 1).

\section{The Procedures}

As it was difficult to conduct a systematic review or metaanalysis, we decided to conduct a scoping review. Based on the literature we collected and selected, we summarized two broad themes to organize the review (Table 1). And this study mainly focuses on examining if a home garden and home gardening promote mental health directly or indirectly during and after the COVID-19 pandemic:

(1) To think about the solutions of mental health needs during the lockdowns period of the COVID-19 pandemic, the articles discussing the benefits of green space (home garden) or gardening on mental health were searched and collected. 


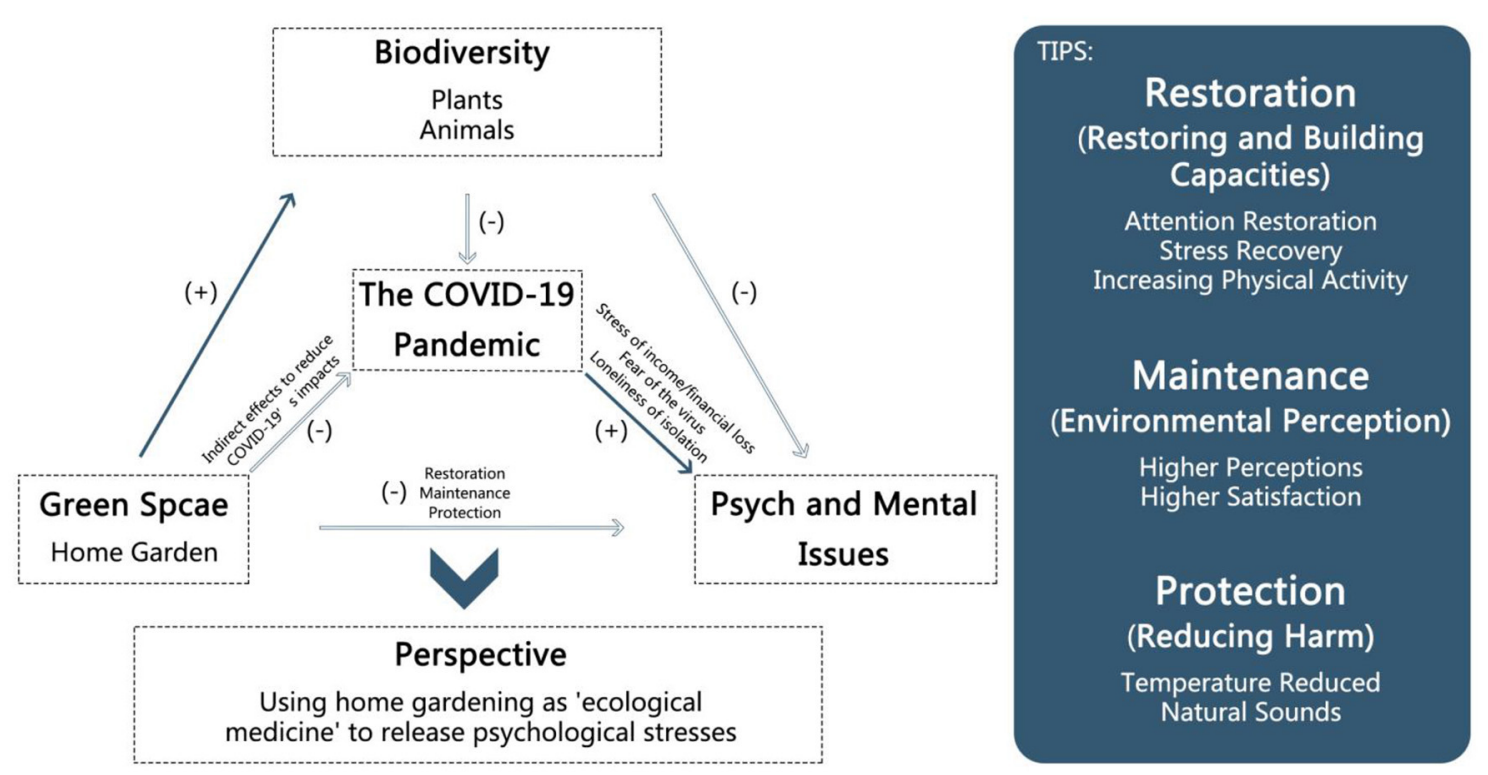

FIGURE 1 | The conceptual model of effects of green space/home garden on reducing mental problems under the pandemic (scenario) and benefiting biodiversity. It shows the logical framework of the green space with eco-healing effects. To control the COVID-19 pandemic, stay-at-home advisories or shelter-in-place policies were published. But, on the other hand, some mental issues including the feelings of stress, fear, and loneliness increased. Green space as one nature-based solution has been proven to relieve mental problems and stress through restoration (restoring and building capacities), maintenance (environmental perception), and protection (protection). And it also increases urban biodiversity through plants and animals. Due to the low likelihood of people accessing public green spaces, a home garden is mentioned. So the home garden, a kind of green space at a small scale, is good for mental health during the COVID-19 pandemic and has an indirect positive effect on combating the challenges of the pandemic. Thus, the idea of using green space, a kind of natural solution, to improve mental health and urban biodiversity not only during the pandemic but also in daily life is raised.

TABLE 1 | The table shows some literature discussing aspects of (A) the positive influence of a home garden on mental health; (B) the promoting effects of home gardening (a kind of physical activity) on mental health.

\section{Study characteristics}

(A) The positive influence of a home garden on mental health

keywords: green space, home garden, balcony garden, biodiversity, psychological health, mental health

\begin{tabular}{ll}
\hline Aspect & Study
\end{tabular}

(i) More areas with green space can result in better mental health;

(ii) More frequently entering into green space can lead to fewer mental problems;

(iii) Green spaces improve mental health through three main stages, including restoration, maintenance, and protection;

(iv) Biodiversity makes significant contributions to mental health;

(v) Contact with nature can reduce stress, anxiety, and other negative emotions.
Almanza et al. (30); Annerstedt et al. (31); Arslan et al. (32); Campbell et al. (25); Carrus et al. (33); Cox et al. (34); Cracknell et al. (35); Dadvand et al. (28); De Jong et al. (36); De Vries et al. (37); DeSchriver and Riddick (38); Dong et al. (39); Dzhambov et al. (40); Engemann et al. (20); Fuller et al. (41); Fuller and Gaston (42); Gascon et al. (43); Gascon et al. (44); Goldstein et al. (45); Grahn et al. (46); Han, (47); Hartig et al. (21); Hartig and Kahn (48); Jackson (26); Kumar et al. (22); Li et al. (49); Markevych et al. (50); Mitchell (51); Mytton et al. (52); Sarkar et al. (53); Taylor and Hochuli (27); Tzoulas et al. (23); Ulrich et al. (54); Van den Berg et al. (24); Van Renterghem (55); Wells (56); White et al. (57); Wild-Eck (58); Wilkie et al. (59); Wilkie et al. (60); Wu et al. (61); Young et al. (62).

\section{(B) The promotion of home gardening on mental health}

keywords: home gardening, psychological health, mental health

Aspect Study

(i) Home gardening can be good for mental health through relaxation and restoration;

(ii) Home gardening can strengthen human contact with the natural environment;

(iii) Home gardening can improve physical health to promote mental health.

Chalmin-Pui et al. (63); Chang et al. (64); Corley et al. (65); Dennis et al. (66); Dzhambov et al. (67); Korn et al. (68); Lachowycz and Jones (69); Lakhani et al. (70); Pouso et al. (71); Sofo and Sofo (72); Soga et al. (73); Theodorou et al. (74) 
The mental health benefits of exposure to nature can be found in both direct and indirect aspects. The direct aspect is about the benefits of nature factors, such as natural colors, natural sounds, and animals, while the indirect aspect is about benefits like increasing physical activities.

(2) The mechanisms of a home garden and home gardening on mental health promotion were also analyzed by summarizing and exploring the benefits of gardens' components including water, plants, animals, and so on. And then we developed a framework about the benefits between home garden/home gardening and mental health. The framework can be used not only during the COVID-19 pandemic but also after it.

\section{RESULTS}

\section{Overview: Effects of a Home Garden and Home Gardening on Promoting Mental Health}

Green spaces including home gardens and balcony gardens have positive influences on mental health (Table 1A), and home gardening also has a promoting effect on mental health (Table 1B). Thus, during and after the COVID-19 pandemic, green space (home garden) will be "ecological medicine" for mental health.

\section{Analysis: Odds Ratios for Describing the Positive Effects}

Green spaces have positive effects on improving mental health $(42,53)$. People living closer to urban green spaces are often associated with lower mental distress (57) because of the buffering effect of green space in reducing negative feelings, such as depression and anxiety (Figure 2). And it can promote mental health through sight, hearing, touch, and smell. The relationship between greenness and the individual situation of Figure 2 is reflected by odds ratio (OR) which uses Equation (1):

$$
O R=\frac{A / B}{C / D}=\frac{A D}{B C}
$$

A: number of exposed persons in the case group.

B: number of non-exposed persons in the case group.

C: number of exposed people in the control group.

$\mathrm{D}$ : number of non-exposed people in the control group.

A home garden acts as an important kind of green space in a balcony or courtyard, it can also provide space for home gardening so that people can reduce mental problems through physical exercise. Green space complexity can vary dramatically in contributing to benefiting human mental health, and green spaces with higher species richness can also have greater mental benefits (41).

\section{DISCUSSION}

\section{The Home Garden as "Ecological Medicine" During the COVID-19 Pandemic}

In order to control the spread of the COVID-19 pandemic, governments quickly took protective measures, such as closing public places like shopping malls, gyms, and schools, and also discouraging social gatherings. In addition, many countries took stricter measures, such as imposing total lockdowns or even curfews (75). However, such measures have led to a more sedentary shift to unhealthy lifestyles through people staying away from work, schools, or gyms $(76,77)$.

A study investigating the effects of stay-at-home policies taken during the COVID-19 pandemic on human eating behaviors, physical activities, and body weight showed that participants spent less time exercising and more time sitting or lying each day, which would lead to weight gain (78). Therefore, policy interventions to ensure control of the COVID19 pandemic should be accompanied by attention to maintaining a healthy lifestyle.

In this context, a home garden, an important part of green space, becomes the preferred option to deal with the dual pressure of lockdown policies and mental health needs. A study of physical and mental health effects of a home garden using among older adults in Scotland during the COVID-19 pandemic suggested that a home garden had positive benefits on subjective well-being, including physical and mental health (65).

It has also indicated that a home garden promotes mental health through not only itself but also activities such as home gardening. On the one hand, a home garden, along with other types of green space, provides opportunities for people to interact directly with nature which is beneficial to mental health $(79,80)$. A home garden can provide people with sunshine and fresh air, which can have indirect mental health benefits, including helping with sleep and eating patterns $(81,82)$. In addition, spending time in a home garden involves physical activities, which can promote physical strength, health, and flexibility, and additionally, provide mental health benefits (83). And it also shows that spending time in a home garden can provide opportunities for people to interact with their neighbors while obeying social distancing, thereby promoting a sense of community and social connection, and also indirectly improving mental health (37) especially during the lockdowns.

Thus, a home garden as a potential health resource can play the role of "ecological medicine" during the COVID-19 pandemic. Following on, this article will focus on discussing (a) the mechanisms of a home garden on mental health, and (b) the positive effects of home gardening on mental health.

\section{The Mechanisms of a Home Garden Promoting Mental Health During the COVID-19 Pandemic}

A home garden is a small ecosystem which can provide ecosystem services, and enhance human health at a small scale, including improving mental health, mitigating allergies, and reducing allcause, respiratory, cardiovascular, and cancer mortality (84). And it also shows that a home garden can benefit mental health directly through three main stages: (a) restoration, i.e., recovery from stress (37), (b) maintenance $(40,44,50)$, and (c) protection $(37,40,44,50)$.

People with mental problems will show high stress, low attention, and low interest. A home garden has been proved 


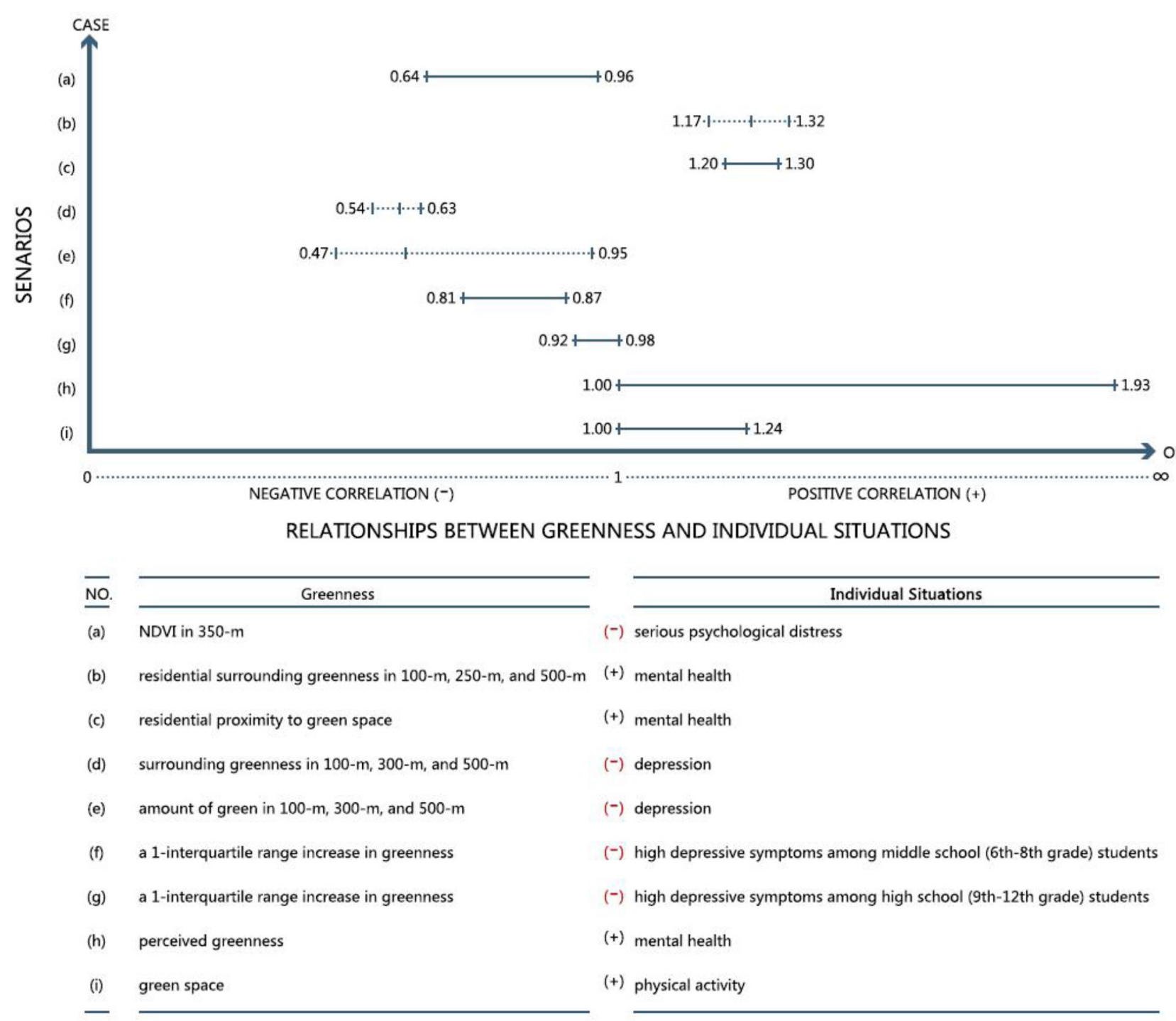

FIGURE 2 | By searching data from the previous studies, the relationship between greenness and individual situation (see Appendix A for references) is reflected by odds ratios (ORs). If the $\mathrm{OR}<1$, it means that there is a negative correlation between the two factors. And it will be positive between two factors if the OR is more than one. There are four pairs of relationships that are positively correlated: (b) residential surrounding greenness and mental health, (c) residential surrounding greenness and mental health, (h) perceived greenness and mental health, and (i) green space and physical activity, which indicate that greenness will promote mental health and physical activity. In addition, negative correlations of scenarios with mental problems are: (a) NDVI over $350 \mathrm{~m}$, which represents the greenness assessed by the Normalized Difference Vegetation Index (NDVI) surrounding a residence over $350 \mathrm{~m}$, (d) surrounding greenness over 100, 300, and 500 m, (e) amount of green over 100, 300, and $500 \mathrm{~m}$, and (f) (g) a 1-interquartile range increase in greenness. The solid lines represent the range of the relationship, and the dashed lines indicate the potential range of the relationship.

to improve mental health through restoring capacities, which means attention restoration $(54,59,60)$, stress recovery $(46,85)$, and increasing physical activity $(51,52)$. A study taken among 116 college students in Taiwan showed that 15 -min exercise in an area with at least $40 \%$ visible greenery was good for attention restoration (47). Higher green levels will result in lower stress levels (85), and the more time and higher frequency of access to green space can also lead to less stress (46). In addition, greenness is also positively correlated with the frequency of physical activity (52). A survey taken in California showed that children would exercise more frequently in locations with more green space than in locations with less green space (30).

And maintenance means that higher perceived green space and satisfaction of the residential environment can potentially maintain mental health $(36,39,69)$, and the higher levels of greenness will result in higher levels of satisfaction. The greenery visible from home and in the neighborhood was associated with a decrease in depression and anxiety symptoms. More houseplants indoors or in gardens are associated with better mental health, which supports the 
hypothesis of the mental health-support effects of indoor greenery (67).

During the COVID-19 pandemic, in addition to the pandemic itself, some environmental factors, such as a climate changerelated urban heat island, can also affect mental health. Research has indicated that climate change can affect mental health indirectly through affecting physical health, for example, extreme heat can cause heat stroke in vulnerable people and lead to mental health problems, including an increased suicide rate (86). Green spaces with trees and vegetation can lower land surface temperature by providing shade and through evapotranspiration, and a study in Suzhou, China showed that a 10\% increase in green space coverage was associated with a $1.41^{\circ} \mathrm{C}$ reduction in surface temperature (61), which could reduce the urban heat island effect to release the pressure of heat stroke. In a similar way, a home garden and active interactions with indoor plants can also be an interactive ecological buffer that reduces mental stress through suppressing sympathetic nervous system activity and promoting feelings of comfort, soothing, and naturalness (87), which then, improves mental health during the pandemic.

In general, a home garden can provide the sustainable use of natural resources and ecosystem services through plants, in terms of health, economic, productive effects (72), and it can also make a beneficial contribution to urban biodiversity conservation (88). Though the lockdowns during the pandemic reduced the likelihood of people encountering outdoor green space, the home garden can be a new way to replace public green space and improve mental health through restoration, maintenance, and protection.

\section{The Positive Effects of Home Gardening, a Kind of Physical Activity, on Mental Health}

Research has found that mental health is positively associated with the frequency of access to green space and the presence of green window views (the greenery outside the window brought by the community greenery, balcony greenery, courtyard greenery, vertical greenery, and so on) (73), which can also benefit recovery from sickness (89). Based on this, a home garden can be a source of greenery with a significant mitigating effect on mental problems through these two aspects (66), especially during the isolation period of the COVID-19 pandemic.

An online survey taken in April 2020 collected 1,491 adults' reports and showed that there were negative changes in physical activity during the COVID-19 pandemic which was associated with higher depression, anxiety, and stress symptoms (90). In view of this phenomenon, a home garden can be a choice for increasing physical activity, such as home gardening, which is good for mental health $(45,70)$. And a survey among 5,766 gardeners and 249 non-gardeners within the UK showed that gardening at least 2-3 times a week could result in better mental health (63). There was also a similar survey taken during the Italian lockdown from March to May 2020 indicating that participation in gardening activities could promote mental health by reducing stress from the COVID-19 pandemic (74). Due to the isolation policies during the COVID-19 pandemic, people could not go to the park to relax, so the home garden became a good alternative for people to undertake physical activities within a limited area.

While doing home gardening, people can improve mental health not only through taking part in physical activities, but also through getting in touch with nature. Evidence has also shown that plant fragrance or color can improve mental health $(32,41,58,91)$, and natural sounds can relax people and support recovery by suggesting proximity to nature $(31,55)$. In addition, some components and elements of a home garden, such as water (92) and flowering plants (49), were proved to be better for mental health. Besides, medicinal and aromatic plants are also good choices for home gardens which can stimulate the senses of garden users (32).

The isolation policies during the COVID-19 pandemic reduced communication among people and communities, as well as reduced people's access to public green space for exercise. A home garden, as a kind of green space which can be built in balconies, yards, or other areas, can increase the likelihood of exposure to green space and increase physical activity so that it can benefit mental health not only in high-income areas but also in low-income communities (68).

Therefore, a green space/home garden can play a role of "ecological medicine" and a natural solution to reduce mental problems during and after the pandemic. And home gardening has also been proved to be good for mental health (93). In the lack of access to green space (69) during the lockdown period of the COVID-19 pandemic, a home garden, a small-scale green space, becomes a rational alternative for contacting greenery (65) by increasing the frequency of access to green space and increasing physical activities.

\section{RECOMMENDATIONS}

\section{"Ecological Medicine" for Achieving Mental Health Through Natural Solutions Using a Home Garden}

The World Health Organization (WHO) defined human health as "a state of complete physical, mental, and social well-being and not merely the absence of disease or infirmity" in 1948, and the definition has not been amended since then. While fighting with the COVID-19 pandemic, we cannot ignore the increasing number and harm of mental problems. So "ecological medicine," a kind of natural solution, will become a good choice to achieve mental health when a lot of medical resources are invested in the treatment of the virus (Figure 3).

"Ecological medicine" as a nature-based method can deal with issues of mental problems during the isolation and physical distance period through ecosystem services from a home garden. Some ecosystem services are related to human health and wellbeing, such as mitigating allergies, heat, noise, and air pollution, as well as improving mental health (84). A national survey taken in Singapore by online questionnaires among 1,262 people showed that high life satisfaction, which improved mental health, was positively associated with nature experiences and views from windows (64). 


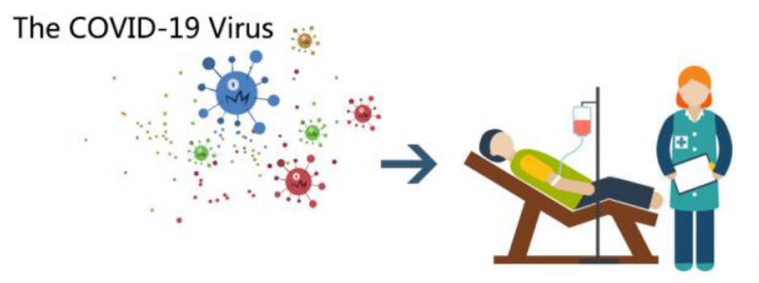

Physical Disorders
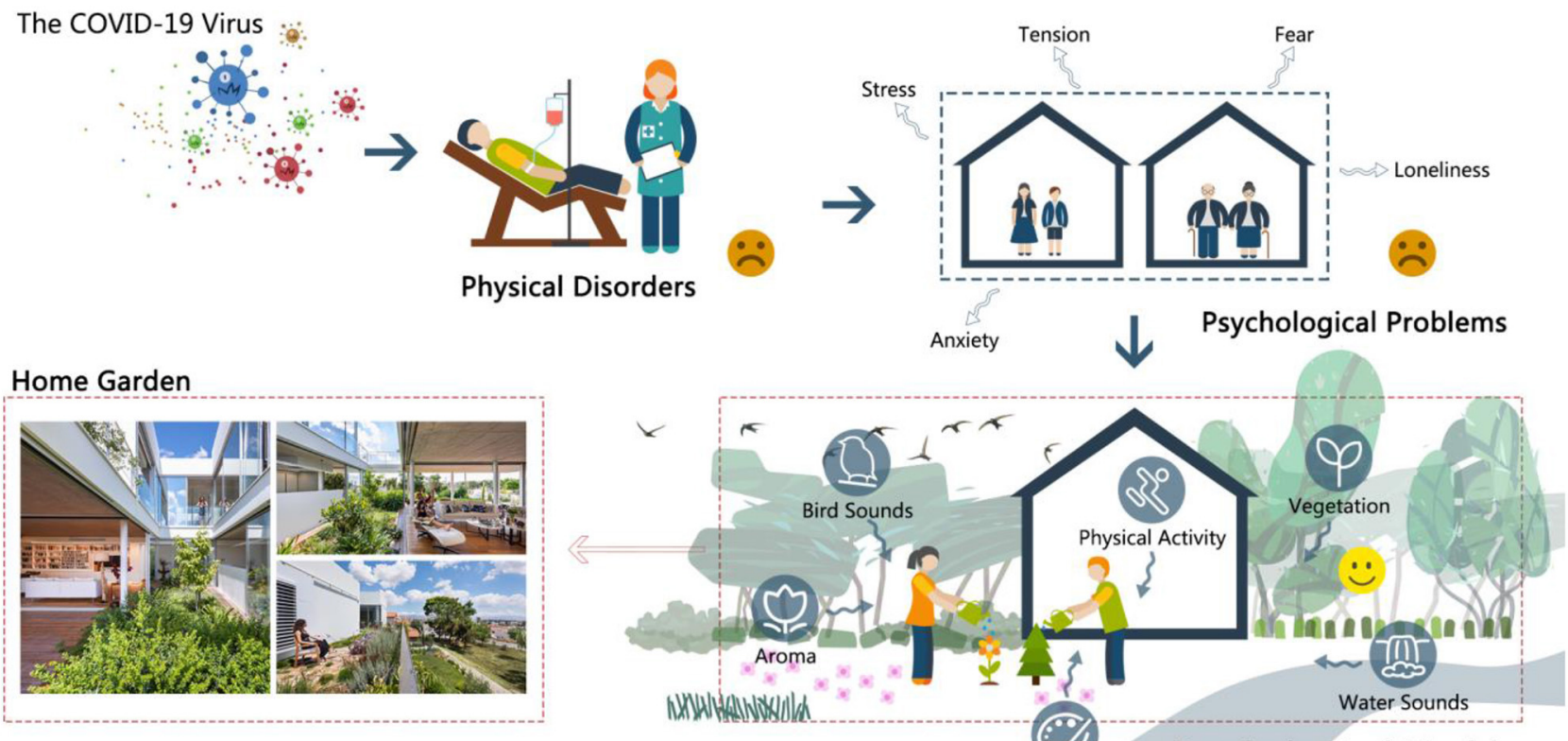

Psychological Health

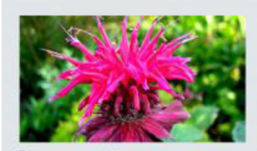

Bergamot

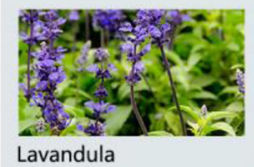

Lavandula

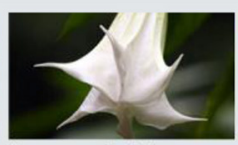

Brugmansia Arborea

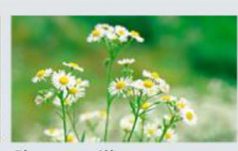

Chamomilla

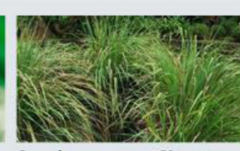

Cymbopogon Citratus Cyperus Prolixus

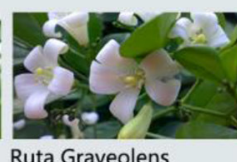

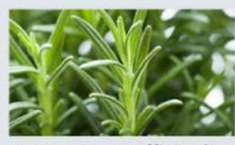
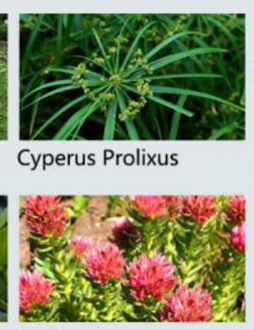

Sedum Rosea

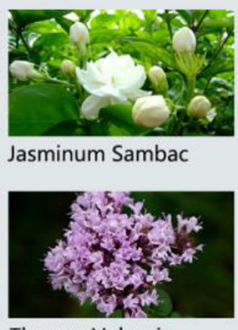

Thymus Vulgaris

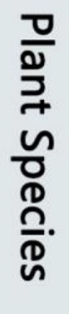

FIGURE 3 | The diagram shows the mechanisms of "ecological medicine" in which the logical framework is discussed in Figure 1. And the diagram also shows some plant species in a home garden for mental health. The government gives stay-at-home advisories or shelter-in-place policies in order to control the spread of the COVID-19 pandemic. However, people will feel stress, tension, fear, anxiety, and loneliness due to isolation from society. A home garden, a kind of green space, can improve mental health through natural sounds (birds sounds or water sounds), aroma, color, and vegetation, and it can also benefit biodiversity through more kinds of plants and animals. What is more, it can also increase the frequency of physical activity, such as home gardening, which can give people opportunities to get in contact with nature and release mental stress to improve mental health, as well as benefit biodiversity conservation. The benefits of these can be summarized into three stages: restoration (attention restoration, stress recovery, and increasing physical activity), maintenance (higher quality of green space and residential environment can potentially maintain mental health), and protection (home garden as a buffer between human and harm from the environment). And the pathway of this is called "ecological medicine" which is a kind of nature-based solution. Image (left-down picture of a home garden): https://mooool.com/the-garden-house-inthe-city-by-christos-pavlou-architecture.html.

Many studies have indicated that a home garden can improve mental health through increasing physical activity (45, 63, 70). Flowering plants in a home garden have better effects on mental health than foliage plants. A study among 150 college students showed a 10-min image of an impact to participants in order to elicit stress. After $5 \mathrm{~min}$ of recovery, the participants were randomly divided into three groups: those that looked at (a) red geraniums, (b) only green leaves, and (c) nothing. The results showed that the participants significantly recovered from the pressure after seeing the red-flowered geranium, and it was very obvious compared with the other two groups (49).

Additionally, higher biodiversity was shown to be greater for mental benefits by a study taken in the UK among 79 participants $\left(N_{1}=39 ; N_{2}=40\right)$ (35). And a home garden constitutes a key center for biodiversity conservation (94). In a home garden, medicinal and aromatic plants can significantly increase biodiversity (95) and be good choices for healing because they stimulate the senses of garden users to relieve mental disorders (32). According to the WHO (World Health Organization), (96), around $80 \%$ of people in all developing countries use medicinal plants as a primary source of health care and sometimes as the only available treatment. And some studies have shown that many kinds of plants, such as Brugmansia arborea, Cyperus prolixus, and Ruta graveolens, can be used to treat bad moods (95).

However, allergenic plants should be avoided in a home garden as they can be associated with the prevalence of allergy 
diseases (97), which will cause more serious mental distress. It has been indicated that exposure to pollen from some allergenic plants is associated with severe allergy symptoms (98). Therefore, we need to pay special attention to control the application of allergenic plants (especially flowers that undergo pollination by wind, e.g., plant species belonging to genera Acer, Tilia, Betula, Populus, Platanus, Celtis, Aesculus, Thuja, Ulmus, Robinia, and Quercus) (99) and increase the area of non-allergenic plants, so as to reduce the pollen concentration of allergenic plants in the air.

What is more, being surrounded by natural sounds (birds sounds or water sounds) has been proved to be helpful to reduce stress (31) through relaxing people and supporting recovery by suggesting proximity to nature (55). It has also been proved that animal watching not only makes participants lower their pulse rate and muscle tone, and increase their skin temperature, but also provides positive natural feelings to benefit mental health $(38,56)$.

In order to control the spread of the virus, the U.S. government established stay-at-home advisories or shelter-inplace policies to implement extraordinary physical distance interventions so that people could not access community green spaces, parks, and other public places for activities $(8,100)$. However, a home garden as a green space at a small scale has been proved to be beneficial to mental health by increasing the frequency of access to green space, views from windows, and physical activity. During the isolation period of the COVID-19 pandemic, a home garden became a new choice for people to get in touch with nature. So people could use their balconies or private courtyards for gardening and build their own home gardens to make contact with nature and release stress, and relieve loneliness and other mental problems. And in a home garden, flowering, medicinal, and aromatic plants will be better for mental health $(32,49)$. Natural sounds from birds or water are also proved to be good for mental health $(31,55)$. With these findings, people can design and build their home gardens to relax and exercise for their mental health.

During the COVID-19 pandemic, people could use this "ecological medicine" as a new way to maintain mental health through a home garden and home gardening which are less harmful and more sustainable ways to reduce stress, tension, fear, anxiety, and loneliness from the virus or the lockdowns and improve their mental health.

\section{CONCLUSIONS}

The COVID-19 pandemic has disrupted the normal rhythm of life in the world over the past 17 months, and will continue to affect people's health for an uncertain period of time, especially mental health (101-107). Due to the shortage of mental health professionals and the sharply increasing demand for mental assistance or interventions for the general population (108-110), it is urgent and crucial to define rational nature-based practices that are developed for mental health care (111). The stay-at-home and lockdown policies during the COVID-19 pandemic have made home gardens a rational alternative choice for promoting mental health.

\section{Home Garden, a Small-Scale Green Space, Can Promote Mental Health With Home Gardening}

Home garden/home gardening can be "ecological medicine" to provide mental health benefits through restoration, maintenance, and protection during the isolation policies. In home gardens, people cannot only get in close contact with nature through sensual messages (touching, seeing, smelling, and listening), but also divert their negative emotions through gardening and release the pressure of mental disorders. Additionally, home gardening along with urban green nature has great potential to be a "naturebased solution" for improving public mental health during the pandemic, and it can also indirectly contribute to the control of the COVID-19 pandemic.

\section{Biodiversity Increasing due to Home Gardens for Mental Health}

Mental benefits are also positively associated with the biodiversity of plants and animals $(33,34,62)$. There is also evidence that green spaces with wildlife may be better for mental health because they can provoke a sense of connection with the whole of nature (91), and afternoon bird abundances can benefit wellbeing through increasing interactions (34). A home garden can be a kind of small green space in urban areas benefiting mental health, and a complex network of home gardens in cities can provide a positive effect on improving urban biodiversity (112).

\section{"Ecological Medicine" Is an Efficient Healing Alternative to Improve Mental Health-Nature Experience as a Determinant of Mental Health}

To deal with the negative effects of isolation and social distance policies on mental health, a home garden and gardening can be effective approaches for people re-connecting to green environments to provide a nature experience with eco-healing effects on maintaining mental health, and it may also reduce the health burden due to COVID-induced disability and sequelae across all age groups, including neurocognitive disorders and mental health disorders $(11,113)$. Natural sounds, vegetation color and shape, plant fragrance, and so on coming from a home garden can help improve mental health through sense organs by hearing, seeing, touching, and smelling $(32,41,58,91)$. A home garden, with flowers, animals (e.g., bees, butterflies), medicinal herbs, and so on, not only has the benefits of increasing green habitats and supporting urban biodiversity (plants, animals, and soil microbiome), but also has the advantages of being accessible at any time, with nature experience (gardening) effects on cognitive functioning, emotional well-being, and other multiple dimensions of mental health. Balconies, backyards, or courtyards can be designed and built with effective nature-based solutions with eco-healing effects to improve public mental health during lockdowns of the pandemic and indirectly help contain the COVID-19 pandemic. And in the future, such eco-healing home gardens can be an approach to meet challenges in mental health not only in post COVID-19 pandemic recovery, but also in risks 
of future unknown pandemic surges with isolation and physical distancing regulations.

\section{AUTHOR CONTRIBUTIONS}

$\mathrm{XDZ}$ and YXZ designed this study and wrote the manuscript. JZ discussed this manuscript. All authors contributed to the article and approved the submitted version.

\section{FUNDING}

YXZ's research is partially supported by a grant (p113800618) of Soochow University-Suzhou Yuanke

\section{REFERENCES}

1. Johns Hopkins University and Medicine. Coronavirus Resource Center. (2021). Available online at: https://coronavirus.jhu.edu/ (accessed May 8, 2021).

2. Benke C, Autenrieth LK, Asselmann E, Pane-Farre CA. Lockdown, quarantine measures, and social distancing: associations with depression, anxiety and distress at the beginning of the COVID19 pandemic among adults from Germany. Psychiatry Res. (2020) 293:113462. doi: 10.1016/j.psychres.2020.113462

3. Mazza C, Ricci E, Biondi S, Colasanti M, Ferracuti S, Napoli C, et al. Nationwide Survey of psychological distress among Italian people during the COVID-19 pandemic: immediate psychological responses and associated factors. Int $J$ Environ Res Public Health. (2020) 17:3165. doi: 10.3390/ijerph170 93165

4. Ettman CK, Abdalla SM, Cohen GH, Sampson L, Vivier PM, Galea S. Prevalence of depression symptoms in US adults before and during the COVID-19 pandemic. JAMA Network Open. (2020) 3:e2019686. doi: 10.1001/jamanetworkopen.2020.19686

5. Holmes EA, O'Connor RC, Perry VH, Tracey I, Wessely S, Arseneault L, et al. Multidisciplinary research priorities for the COVID-19 pandemic: a call for action for mental health science. Lancet Psychiatry. (2020) 7:54760. doi: 10.1016/S2215-0366(20)30168-1

6. Mertens G, Gerritsenb L, Duijndama S, Saleminkb E, Engelhard IM. Fear of the coronavirus (COVID-19): predictors in an online study conducted in March 2020. J Anxiety Disord. (2020) 74:102258. doi: 10.1016/j.janxdis.2020.102258

7. Torales J, O'Higgins M, Castaldelli-Maia JM, Ventriglio A. The outbreak of COVID-19 coronavirus and its impact on global mental health. Int J Soc Psychiatry. (2020) 66:317-20. doi: 10.1177/0020764020915212

8. Tull MT, Edmonds KA, Scamaldo K, Richmond JR, Rose JP, Gratz KL. Psychological outcomes associated with stay-at-home orders and the perceived impact of COVID-19 on daily life. Psychiatry Res. (2020) 289:113098. doi: 10.1016/j.psychres.2020.113098

9. Wang C, Pan RY, Wan XY, Tan YL, Xu LK, Ho CS, et al. Immediate psychological responses and associated factors during the initial stage of the 2019 coronavirus disease (COVID-19) epidemic among the general population in China. Int J Environ Res Public Health. (2020) 17:170529. doi: 10.3390/ijerph17051729

10. Abbott A. COVID's mental-health toll: scientists track surge in depression. Nature. (2021) 590:194-5. doi: 10.1038/d41586-021-00175-Z

11. Al-Aly $\mathrm{Z}$, Xie Y, Bowe B. High-dimensional characterization of post-acute sequelae of COVID-19. Nature. (2021) 594:259. doi: 10.1038/s41586-021-03553-9

12. Rajkumar RP. COVID-19 and mental health: a review of the existing literature. Asian J Psychiatr. (2020) 52:102066. doi: 10.1016/j.ajp.2020. 102066
(SU-SY) Collaborative Innovation Center of Architecture and Urban Environment. This project was also supported by the National Key Research and Development Program of China (grant no. 2021YFE0200100; China-Portugal Belt and Road Cooperation Laboratory of Cultural Heritage Conservation Science).

\section{ACKNOWLEDGMENTS}

The authors wish to thank the reviewers for their constructive comments and rational suggestions, which helped us to significantly improve this manuscript. YXZ thank the SU-SY Collaborative Innovation Center.

13. Dubey S, Biswas P, Ghosh R, Chatterjee S, Dubey MJ, Chatterjee S, et al. Psychosocial impact of COVID-19. Diabetes Metab Syndr. (2020) 14:77988. doi: 10.1016/j.dsx.2020.05.035

14. Kessler RC, Demler O, Frank RG, Olfson M, Pincus HA, Walters EE, et al. Prevalence and treatment of mental disorders, 1990 to 2003. N Engl J Med. (2005) 352:2515-23. doi: 10.1056/NEJMsa043266

15. Mojtabai R. Increase in antidepressant medication in the US adult population between 1990 and 2003. Psychother Psychosom. (2008) 77:8392. doi: $10.1159 / 000112885$

16. Paulose-Ram R, Safran MA, Jonas BS, Gu Q, Orwig D. Trends in psychotropic medication use among U.S. adults. Pharmacoepidemiol Drug Saf. (2007). 16, 560-70. doi: 10.1002/pds.1367

17. Currier JM, McDermott RC, McCormick WH. Mental health treatmentrelated stigma and professional help seeking among student veterans. Psychol Serv. (2017) 14:531-42. doi: 10.1037/ser0000129

18. Stowell DR, Owens GP, Burnett A. A pilot horticultural therapy program serving veterans with mental health issues: feasibility and outcomes. Complement Ther Clin Pract. (2018) 32:74-8. doi: 10.1016/j.ctcp.2018. 05.007

19. Siu AMH, Kam M, Ide Mok I. Horticultural therapy program for people with mental illness: a mixed-method evaluation. Int J Environ Res Public Health. (2020) 17:711. doi: 10.3390/ijerph17030711

20. Engemann K, Pedersen CB, Arge L, Tsirogiannis C, Mortensen PB, Svenning JC. Residential green space in childhood is associated with lower risk of psychiatric disorders from adolescence into adulthood. Proc Natl Acad Sci USA. (2019) 116:5188-93. doi: 10.1073/pnas.180 7504116

21. Hartig T, Mitchell R, Vries S, Frumkin H. Nature and health. Annu Rev Public Health. (2014) 35:207-28. doi: 10.1146/annurev-publhealth-032013-182443

22. Kumar P, Druckman A, Gallagher J, Gatersleben B, Allison S, Eisenman TS, et al. The nexus between air pollution, green infrastructure and human health. Environ Int. (2019) 133:105181. doi: 10.1016/j.envint.2019.105181

23. Tzoulas K, Korpela K, Venn S, Yli-Pelkonen V, Kazmierczak A, Niemela J, et al. Promoting ecosystem and human health in urban areas using Green Infrastructure: a literature review. Landsc Urban Plan. (2007) 81:16778. doi: 10.1016/j.landurbplan.2007.02.001

24. Van den Berg AE, Maas J, Verheij RA, Groenewegen PP. Green space as a buffer between stressful life events and health. Soc Sci Med. (2010) 70:1203-10. doi: 10.1016/j.socscimed.2010.01.002

25. Campbell K, Cooper D, Dias B, Prieur-Richard AH, Campbell-Lendrum D, Karesh WB, et al. Strengthening international cooperation for health and biodiversity. Ecohealth. (2011) 8:407-9. doi: 10.1007/s10393-012-0764-8

26. Jackson LE. The relationship of urban design to human health and condition. Landsc Urban Plan. (2003) 64:191200. doi: 10.1016/S0169-2046(02)00230-X

27. Taylor L, Hochuli DF. Creating better cities: how biodiversity and ecosystem functioning enhance urban residents' wellbeing. Urban Ecosyst. (2015) 18:747-62. doi: 10.1007/s11252-014-0427-3 
28. Dadvand $\mathrm{P}$, Bartoll $\mathrm{X}$, Basagaña $\mathrm{X}$, Dalmau-Bueno $\mathrm{A}$, Martinez $\mathrm{D}$, Ambros A, et al. Green space and general health: roles of mental health status, social support, and physical activity. Environ Int. (2016) 91:1617. doi: 10.1016/j.envint.2016.02.029

29. Bratman GN, Anderson CB, Berman MG, Cochran B, de Vries S, Flanders J, et al. Nature and mental health: an ecosystem service perspective. Sci Adv. (2019) 5:0903. doi: 10.1126/sciadv.aax0903

30. Almanza E, Jerrett M, Dunton G, Seto E, Pentz MAA. A study of community design, greenness, and physical activity in children using satellite, GPS and accelerometer data. Health Place. (2012) 18:4654. doi: 10.1016/j.healthplace.2011.09.003

31. Annerstedt M, Jönsson P, Wallergård M, Johansson G, Karlson B, Grahn $\mathrm{P}$, et al. Inducing physiological stress recovery with sounds of nature in a virtual reality forest - results from a pilot study. Physiol Behav. (2013) 118:240-50. doi: 10.1016/j.physbeh.2013.05.023

32. Arslan M, Kalaylioglu Z, Ekren E. Use of medicinal and aromatic plants in therapeutic gardens. Ind J Pharmaceut Educ Res. (2018) 52:S1514. doi: 10.5530/ijper.52.4s.92

33. Carrus G, Scopelliti M, Lafortezza R, Colangelo G, Ferrini F, Salbitano F, et al. Go greener, feel better? The positive effects of biodiversity on thewell-beingof individuals visiting urban and peri-urban green areas. Landsc Urban Plann. (2015) 134:221-8. doi: 10.1016/j.landurbplan.2014.10.022

34. Cox DLC, Shanahan DF, Hudson HL, Plummer KE, Siriwardena GM, Fuller RA, et al. Doses of neighborhood nature: the benefits for mental health of living with nature. Bioscience. (2017) 67:147-55. doi: 10.1093/biosci/biw173

35. Cracknell D, White MP, Pahl S, Depledge MH. A preliminary investigation into the restorative potential of public aquaria exhibits: a UK studentbased study. Landsc Res. (2016) 42:18-32. doi: 10.1080/01426397.2016. 1243236

36. De Jong K, Albin M, Skärbäck E, Grahn P, Björk J. Perceived green qualities were associated with neighborhood satisfaction, physical activity, and general health: results from a cross-sectional study in suburban and rural Scania, southern Sweden. Health Place. (2012) 18:137480. doi: 10.1016/j.healthplace.2012.07.001

37. De Vries S, Van Dillen SME, Groenewegen PP, Spreeuwenberg P. Streetscape greenery and health: stress, social cohesion and physical activity as mediators. Soc Sci Med. (2013) 94:26-33. doi: 10.1016/j.socscimed.2013.06.030

38. DeSchriver MM, Riddick CC. Effects of watching aquariums on elders' stress. Anthrozoös. (2015) 4:44-8. doi: 10.2752/089279391787057396

39. Dong H, Qin B. Exploring the link between neighborhood environment and mental wellbeing: a case study in Beijing, China. Landsc Urban Plan. (2017) 164:71-80. doi: 10.1016/j.landurbplan.2017.04.005

40. Dzhambov AM, Markevych I, Hartig T, Tilov B, Arabadzhiev Z, Stoyanov D, et al. Multiple pathways link urban green and bluespace to mental health in young adults. Environ Res. (2018) 166:223-33. doi: 10.1016/j.envres.2018.06.004

41. Fuller RA, Irvine $\mathrm{KN}$, Devine-Wright $\mathrm{P}$, Warren $\mathrm{PH}$, Gaston KJ. Psychological benefits of green space increase with biodiversity. Biol Lett. (2007) 3:390-4. doi: 10.1098/rsbl.2007.0149

42. Fuller RA, Gaston KJ. The scaling of green space coverage in European cities. Biol Lett. (2009) 5:352-5. doi: 10.1098/rsbl.2009.0010

43. Gascon M, Triguero-Mas M, Martinez D, Dadvand P, Forns J, Plasència A, et al. Mental health benefits of long-term exposure to residential green and blue spaces: a systematic review. Int J Environ Res Public Health. (2015) 12:4354-79. doi: 10.3390/ijerph120404354

44. Gascon M, Sánchez-Benavides G, Dadvand P, Martínez D, Gramunt N, Gotsens X, et al. Long-term exposure to residential green and blue spaces and anxiety and depression in adults: a cross-sectional study. Environ Res. (2018) 162:231-9. doi: 10.1016/j.envres.2018.01.012

45. Goldstein E, Topitzes J, Brown RL, Barrett B. Mediational pathways of meditation and exercise on mental health and perceived stress: a randomized controlled trial. J Health Psychol. (2018) 25:1816-30. doi: 10.1177/1359105318772608

46. Grahn P, Stigsdotter UA. Landscape planning and stress. Urban Forest Urban Green. (2003) 2:1-18. doi: 10.1078/1618-8667-00019

47. Han KT. The effect of nature and physical activity on emotions and attention while engaging in green exercise. Urban Forest Urban Green. (2017) 24:513. doi: 10.1016/j.ufug.2017.03.012
48. Hartig T, Kahn PHJr. Living in cities, naturally. Nature. (2016) 352:9834. doi: 10.1126/science.aaf3759

49. Li SH, Zhang WX. Progress in horticultural therapy scientific research. Chin Landsc Architect. (2009) 8:19-23.

50. Markevych I, Schoierer J, Hartig T, Chudnovsky A, Hystad P, Dzhambov AM, et al. Exploring pathways linking greenspace to health: theoretical and methodological guidance. Environ Res. (2017) 158:301-17. doi: 10.1016/j.envres.2017.06.028

51. Mitchell R. Is physical activity in natural environments better for mental health than physical activity in other environments? Soc. Sci. Med. (2013) 91:130-4. doi: 10.1016/j.socscimed.2012.04.012

52. Mytton OT, Townsend N, Rutter H, Foster C. Green space and physical activity: an observational study using Health Survey for England data. Health Place. (2012) 18:1034-41. doi: 10.1016/j.healthplace.2012.06.003

53. Sarkar C, Webster C, Gallacher J. Residential greenness and prevalence of major depressive disorders: a cross-sectional, observational, associational study of 94879 adult UK Bio bank participants. Lancet Planet Health. (2018) 2:E162-73. doi: 10.1016/S2542-5196(18)30051-2

54. Ulrich RS, Simons RF, Losito BD, Fiorito E, Miles MA, Zelson M. Stress recovery during exposure to natural and urban environments. J Environ Psychol. (1991) 11:201-30. doi: 10.1016/S0272-4944(05)80184-7

55. Van Renterghem T. Towards explaining the positive effect of vegetation on the perception of environmental noise. Urban Forest Urban Green. (2019) 40:133-44. doi: 10.1016/j.ufug.2018.03.007

56. Wells DL. The effect of videotapes of animals on cardiovascular responses to stress. Stress Health. (2005) 21:209-13. doi: 10.1002/smi.1057

57. White MP, Alcock I, Wheeler BW, Depledge MH. Would you be happier living in a greener urban area? A fixed-effects analysis of panel data. Psychol Sci. (2013) 24:920-8. doi: 10.1177/0956797612464659

58. Wild-Eck S. Perception of urban green spaces and quality of life. J Forest Suisse. (2003) 154:405-9. doi: 10.3188/szf.2003.0405

59. Wilkie S, Clouston L. Environment preference and environment type congruence: effects on perceived restoration potential and restoration outcome. Urban Forest Urban Green. (2015) 14:368-76. doi: 10.1016/j.ufug.2015.03.002

60. Wilkie S, Thompson E, Cranner P, Ginty K. Attention restoration theory as a framework for analysis of Tweets about urban green space: a case study. Landscape Res. (2020). 45:777-88. doi: 10.1080/01426397.2020.1738363

61. Wu ZJ, Zhang YX. Spatial variation of urban thermal environment and its relation to green space patterns: implication to sustainable landscape planning. Sustainability. (2018) 10:2249. doi: 10.3390/su10072249

62. Young C, Hofmann M, Frey D, Moretti M, Bauer N. Psychological restoration in urban gardens related to garden type, biodiversity and garden-related stress. Landsc Urban Plan. (2020) 198:103777. doi: 10.1016/j.landurbplan.2020.103777

63. Chalmin-Pui LS, Griffiths A, Roe J, Heaton T, Cameron R. Why garden?Attitudes and the perceived health benefits of home gardening. Cities. (2021). 112:103118. doi: 10.1016/j.cities.2021.103118

64. Chang CC, Oh RRY, Nghiem TPL, Zhang YC, Tan CLY, Lin BB, et al. Life satisfaction linked to the diversity of nature experiences and nature views from the window. Landsc Urban Plan. (2020) 202:103874. doi: 10.1016/j.landurbplan.2020.103874

65. Corley J, Okely JA, Taylor AM, Page D. Home garden use during COVID19: associations with physical and mental wellbeing in older adults. J Environ Psychol. (2021) 73:101545. doi: 10.1016/j.jenvp.2020.101545

66. Dennis M, James P. Evaluating the relative influence on population health of domestic gardens and green space along a rural-urban gradient. Landsc Urban Plan. (2017) 157:343-51. doi: 10.1016/j.landurbplan.2016.08.009

67. Dzhambov AM, Lercher P, Browning MHEM, Stoyanov D, Petrova N, Novakov S, et al. Does greenery experienced indoors and outdoors provide an escape and support mental health during the COVID-19 quarantine? Environ Res. (2020) 196:110420. doi: 10.1016/j.envres.2020.110420

68. Korn A, Bolton SM, Spencer B, Alarcon JA, Andrews L, Voss JG. Physical and mental health impacts of household gardens in an Urban slum in Lima, Peru. Int J Environ Res Public Health. (2018) 15:1751. doi: 10.3390/ijerph15081751

69. Lachowycz K, Jones AP. Towards a better understanding of the relationship between green space and health: development of a theoretical framework. Landsc Urban Plan. (2013) 118:62-9. doi: 10.1016/j.landurbplan.2012.10.012 
70. Lakhani A, Norwood M, Watling DP, Zeeman H, Kendall E. Using the natural environment to address the psychosocial impact of neurological disability: a systematic review. Health Place. (2019) 55:188-201. doi: 10.1016/j.healthplace.2018.12.002

71. Pouso S, Borja A, Fleming LE, Gómez-Baggethun E, White MP, Uyarra MC. Contact with blue-green spaces during the COVID-19 pandemic lockdown beneficial for mental health. Sci Total Environ. (2021) 756:143984. doi: 10.1016/j.scitotenv.2020.143984

72. Sofo A, Sofo A. Converting home spaces into food gardens at the time of Covid-19 quarantine: all the benefits of plants in this difficult and unprecedented period. Hum Ecol. (2020) 48:131-9. doi: 10.1007/s10745-020-00147-3

73. Soga M, Evans MJ, Tsuchiya K, Fukano Y. A room with a green view: the importance of nearby nature for mental health during the COVID-19 pandemic. Ecol Appl. (2020) 0:e02248. doi: 10.1002/eap.2248

74. Theodorou A, Panno A, Carrus G, Carbone GA, Massullo C, Imperatori C. Stay home, stay safe, stay green: the role of gardening activities on mental health during the Covid-19 home confinement. Urban Forest Urban Green. (2021) 61:127091. doi: 10.1016/j.ufug.2021.127091

75. Abed Alah M, Abdeen S, Kehyayan V. The first few cases and fatalities of Corona Virus Disease 2019 (COVID-19) in the Eastern Mediterranean Region of the World Health Organization: a rapid review. J Infect Public Health. (2020) 13:1367-72. doi: 10.1016/j.jiph.2020.06.009

76. Stockwell S, Trott M, Tully M, Shin J, Barnett Y, Butler L, et al. Changes in physical activity and sedentary behaviours from before to during the COVID-19 pandemic lockdown: a systematic review. BMJ Open Sport Exerc Med. (2021) 7:e000960. doi: 10.1136/bmjsem-2020-000960

77. Violant-Holz V, Gallego-Jiménez MG, González-González CS, MuñozViolant S, Rodríguez MJ, Sansano-Nadal O, et al. Psychological health and physical activity levels during the covid-19 pandemic: a systematic review. Int J Environ Res Public Health. (2020) 17:1-19. doi: 10.3390/ijerph17249419

78. Abed Alah M, Abdeen S, Kehyayan V, Bougmiza I. Impact of staying at home measures during COVID-19 pandemic on the lifestyle of Qatar's population: perceived changes in diet, physical activity, and body weight. Prevent Med Rep. (2021) 24:101545. doi: 10.1016/j.pmedr.2021.101545

79. Cox DT, Gaston KJ. Urban bird feeding: connecting people with nature. PLoS ONE. (2016) 11:e0158717. doi: 10.1371/journal.pone.0158717

80. White MP, Alcock I, Grellier J, Wheeler BW, Hartig T, Warber SL, et al. Spending at least 120 minutes a week in nature is associated with good health and wellbeing. Sci Rep. (2019) 9:7730. doi: 10.1038/s41598-019-44097-3

81. Düzgün G, Akyol AD. Effect of natural sunlight on sleep problems and sleep quality of the elderly staying in the nursing home. Holist Nurs Pract. (2017) 31:295-302. doi: 10.1097/HNP.0000000000000206

82. Park SA, Shoemarker CA, Haub MD. Physical and psychological health conditions of older adults classified as gardeners or nongardeners. HortScience. (2009). 44:206-10. doi: 10.21273/HORTSCI.44.1.206

83. Wang D, MacMillan T. The benefits of gardening for older adults: a systematic review of the literature. Activ Adapt Aging. (2013) 37:15381. doi: $10.1080 / 01924788.2013 .784942$

84. Aerts R, Honnay O, Van Nieuwenhuyse A. Biodiversity and human health: mechanisms and evidence of the positive health effects of diversity in nature and green spaces. Br Med Bull. (2018) 127:5-22. doi: 10.1093/bmb/ldy021

85. Thompson CW, Roe J, Aspinall P, Mitchell R, Clow A, Miller D. More green space is linked to less stress in deprived communities: evidence from salivary cortisol patterns. Landsc Urban Plan. (2012) 105:2219. doi: 10.1016/j.landurbplan.2011.12.015

86. Berry HL, Bowen K, Kjellstrom T. Climate change and mental health: a causal pathways framework. Int J Public Health. (2010) 55:12332. doi: $10.1007 /$ s00038-009-0112-0

87. Lee MS, Lee JY, Park BJ, Miyazaki Y. Interaction with indoor plants may reduce psychological and physiological stress by suppressing autonomic nervous system activity in young adults: a randomized crossover study. $J$ Physiol Anthropol. (2015). 34:21. doi: 10.1186/s40101-015-0060-8

88. Raymond CM, Diduck AP, Buijs A, Boerchers M, Moquin R. Exploring the co-benefits (and costs) of home gardening for biodiversity conservation. Local Environ. (2019) 24:258-73. doi: 10.1080/13549839.2018.1561657

89. Ulrich RS. View through a window may influence recovery from surgery. Science. (1984) 224:420-1. doi: 10.1126/science.6143402
90. Stanton R, To QG, Khalesi S, Williams SL, Alley SJ, Thwaite TL, et al. Depression, anxiety and stress during COVID-19: associations with changes in physical activity, sleep, tobacco and alcohol use in Australian adults. Int $J$ Environ Res Public Health. (2020) 17:4065. doi: 10.3390/ijerph17114065

91. Curtin S. Wildlife tourism: the intangible, psychological benefits of human-wildlife encounters. Curr Issues Tour. (2009) 12:451-74. doi: 10.1080/13683500903042857

92. Ulrich RS. Effects of natural view and urban view on human emotion and physiology. Environ Behav. (1981) 13:52356. doi: 10.1177/0013916581135001

93. Luchetti M, Lee JH, Aschwanden D, Sesker A, Strickhouser JE, Terracciano A, et al. The trajectory of loneliness in response to COVID-19. Amer Psychol. (2020) 75:897-908. doi: 10.1037/amp0000690

94. Calvet-Mir L, Riu-Bosoms C, Gonzalez-Puente M, Ruiz-Mallen I, ReyesGarcía V, Molina JL. The Transmission of home garden knowledge: safeguarding biocultural diversity and enhancing social-ecological resilience. Soc Nat Resourc. (2016) 29:556. doi: 10.1080/08941920.2015.1094711

95. Caballero-Serrano V, McLaren B, Carrasco JC, Alday JG, Fiallos L, Amigo J, et al. Traditional ecological knowledge and medicinal plant diversity in Ecuadorian Amazon home gardens. Glob Ecol Conserv. (2019) 17:e00524. doi: 10.1016/j.gecco.2019.e00524

96. WHO (World Health Organization). WHO Traditional Medicine Strategy: 2014-2023. Geneva: World Health Organization (2013).

97. Aerts R, Stas M, Vanlessen N, Hendrickx M, Bruffaerts N, Hoebeke $\mathrm{L}$, et al. Residential green space and seasonal distress in a cohort of tree pollen allergy patients. Int J Hyg Environ Health. (2020) 223:719. doi: 10.1016/j.ijheh.2019.10.004

98. Stas M, Aerts R, Hendrickx M, Delcloo A, Dendoncker N, Dujardin $\mathrm{S}$, et al. Exposure to green space and pollen allergy symptom severity: a case-crossover study in Belgium. Sci Total Environ. (2021) 781:146682. doi: 10.1016/j.scitotenv.2021.146682

99. Mrdan S, Ljubojević M, Orlović S, Cukanović J, Dulić J. Poisonous and allergenic plant species in preschool's and primary school's yards in the city of Novi Sad. Urban Forest Urban Green. (2017) 25:1129. doi: 10.1016/j.ufug.2017.05.007

100. Mervosh S, Lu D, Swales V. See which states and cities have told residents to stay at home. The New York Times. (2020). Available online at: https://www.nytimes.com/interactive/2020/us/coronavirus-stayat-home-order.html (accessed February 18, 2021).

101. Brooks SK, Webster RK, Smith LE, Woodland L, Wessely S, Greenberg N, et al. The psychological impact of quarantine and how to reduce it: rapid review of the evidence. Lancet. (2020) 395:912-20. doi: 10.1016/S0140-6736(20)30460-8

102. Campion J, Javed A, Sartorius N, Marmot M. Addressing the public mental health challenge of COVID-19. Lancet Psychiatry. (2020) 7:6579. doi: $10.1016 / \mathrm{S} 2215-0366(20) 30240-6$

103. Kola L. Global mental health and COVID-19. Lancet Psychiatry. (2020) 8:655-7. doi: 10.1016/S2215-0366(20)30235-2

104. Pierce M, Hope H, Ford T, Hatch S, Hotopf M, John A, et al. Mental health before and during the COVID-19 pandemic: a longitudinal probability sample survey of the UK population. Lancet Psychiatry. (2020) 7:88392. doi: 10.1016/S2215-0366(20)30308-4

105. Qiu JY, Shen B, Zhao M, Wang Z, Xie B, Xu YF. A nationwide survey of psychological distress among Chinese people in the COVID-19 epidemic: implications and policy recommendations. Gen Psychiatry. (2020) 33. doi: 10.1136/gpsych-2020-100213

106. Song M. Psychological stress responses to COVID-19 and adaptive strategies in China. World Dev. (2020) 136:105107. doi: 10.1016/j.worlddev.2020.105107

107. Xiong J, Lipsitz O, Nasri F, Lui LMW, Gill H, Phan L, et al. Impact of COVID19 pandemic on mental health in the general population: a systematic review. J Affect Disord. (2020) 277:55-64. doi: 10.1016/j.jad.2020.08.001

108. Serafini G, Parmigiani B, Amerio A, Aguglia A, Sher L, Amore, M. The psychological impact of COVID-19 on the mental health in the general population. QJM Int J Med. (2020) 113:529-35. doi: 10.1093/qjmed/hcaa201

109. Duan L, Zhu G. Psychological interventions for people affected by the COVID-19 epidemic. Lancet Psychiatry. (2020). 7:2289. doi: 10.1016/S2215-0366(20)30073-0 
110. Xiang YT, Yang Y, Li W, Zhang L, Zhang Q, Cheung T, et al. Timely mental health care for the 2019 novel coronavirus outbreak is urgently needed. Lancet Psychiatry. (2020) 7:300-2. doi: 10.1016/S2215-0366(20)30046-8

111. Moreno C, Wykes T, Galderisi S, Nordentoft M, Crossley N, Jones $\mathrm{N}$, et al. How mental health care should change as a consequence of the COVID-19 pandemic. Lancet Psychiatry. (2020) 7:813-24. doi: 10.1016/S2215-0366(20)30307-2

112. Francoeur XW, Dagenais D, Paquette A, Dupras J, Messier C. Complexifying the urban lawn improves heat mitigation and arthropod biodiversity. Urban Forest Urban Green. (2021) 60:127007. doi: 10.1016/j.ufug.2021.127007

113. Briggs A, Vassall A. Count the cost of disability caused by COVID-19. Nature. (2021) 593:502-5. doi: 10.1038/d41586-021-01392-2

114. Wang P, Meng YY, Lam V, Ponce N. Green space and serious psychological distress among adults and teens: a population-based study in California. Health Place. (2019) 56:184-90. doi: 10.1016/j.healthplace.2019.02.002

115. Bezold CP, Banay RF, Coull BA, Hart JE, James P, Kubzansky LD, et al. The association between natural environments and depressive symptoms in adolescents living in the United States. J Adolesc Health. (2017) 62:48895. doi: 10.1016/j.jadohealth.2017.10.008

116. Sugiyama T, Leslie E, Giles-Corti B, Owen N. Associations of neighbourhood greenness with physical and mental health: do walking, social coherence and local social interaction explain the relationships? J Epidemiol Commun Health. (2008) 62:e9. doi: 10.1136/jech.2007.06 4287

Conflict of Interest: The authors declare that the research was conducted in the absence of any commercial or financial relationships that could be construed as a potential conflict of interest.

Publisher's Note: All claims expressed in this article are solely those of the authors and do not necessarily represent those of their affiliated organizations, or those of the publisher, the editors and the reviewers. Any product that may be evaluated in this article, or claim that may be made by its manufacturer, is not guaranteed or endorsed by the publisher.

Copyright (c) 2021 Zhang, Zhang and Zhai. This is an open-access article distributed under the terms of the Creative Commons Attribution License (CC BY). The use, distribution or reproduction in other forums is permitted, provided the original author(s) and the copyright owner(s) are credited and that the original publication in this journal is cited, in accordance with accepted academic practice. No use, distribution or reproduction is permitted which does not comply with these terms. 


\section{APPENDIX A}

Table A1 | Odds ratios (ORs) for the association between greenness and individual situations.

\begin{tabular}{|c|c|c|c|c|}
\hline \multicolumn{3}{|c|}{ Model } & \multirow[t]{2}{*}{ OR } & \multirow[t]{2}{*}{ Author } \\
\hline NO. & Greenness & Individual situations & & \\
\hline (a) & NDVI over $350 \mathrm{~m}$ & Serious mental distress & $0.64-0.96$ & Wang et al. (114) \\
\hline (b) & $\begin{array}{l}\text { Residential surrounding greenness over } 100 \text {, } \\
250 \text {, and } 500 \mathrm{~m}\end{array}$ & Mental health & $1.32,1.25$, and 1.17 & Dadvand et al. (28) \\
\hline (c) & Residential proximity to green space & & $1.20-1.30$ & \\
\hline (d) & $\begin{array}{l}\text { Surrounding greenness over } 100,300 \text {, and } \\
500 \mathrm{~m}\end{array}$ & Depression & $0.54,0.59$, and 0.63 & Gascon et al. (44) \\
\hline (e) & Amount of green over 100,300 , and $500 \mathrm{~m}$ & & $0.95,0.47$, and 0.60 & \\
\hline (f) & $\begin{array}{l}\text { A one-interquartile range increase in } \\
\text { greenness }\end{array}$ & $\begin{array}{l}\text { High depressive symptoms among middle school } \\
\text { (6th-8th grade) students }\end{array}$ & $0.81-0.87$ & Bezold et al. (115) \\
\hline (g) & & $\begin{array}{l}\text { High depressive symptoms among high school } \\
\text { (9th-12th grade) students }\end{array}$ & $0.92-0.98$ & \\
\hline (h) & Perceived greenness & Mental health & $1.00-1.93$ & Sugiyama et al. (116) \\
\hline (i) & Green space & Physical activity & $1.00-1.24$ & Mytton et al. (52) \\
\hline
\end{tabular}

Nine pairs of interrelationships were extracted from six articles, and whether the relationships between them were positive or negative was reflected by the odds ratios. 